\title{
新・旧 TOEIC®の予測的妥当性の検証
}

Two Versions of the TOEIC®: A Predictive Validation Study

伊藤彰 浩（西南学院大学）Akihiro Ito, Seinan Gakuin University

島谷浩（熊本大学）Hiroshi Shimatani, Kumamoto University

法 月健 (静岡産業大学) Ken Norizuki, Shizuoka Sangyo University

\begin{abstract}
This paper reports the findings of a predictive validity study on two versions of the Test of English for International Communication ${ }^{\circledR}$ (TOEIC $($ ) in the context of English language education in a Japanese university. Twenty students of English as a foreign language in Japan participated in this study. The study investigated the correlation between TOEIC $®$ scores and grade points that the participants earned in six English language-related subjects taught at the university. Retrospective data such as that collected from interviews with the participants and teachers of English were analyzed in order to qualitatively support the empirical results. The results indicated that TOEIC® can predict academic performances in actual English language classrooms at the university level. Further discussions on employing TOEIC $®$ in the context of English language education in Japan are strongly recommended.
\end{abstract}

問題の所在

Test of English for International Communication ${ }^{\circledR}$ （以下，TOEIC®）は，今や日本 国内にとどまらず，諸外国においても多様な目的で用いられている英語テスト のひとつである。国際ビジネスコミュニケーション協会 (2009) によれば, 
TOEIC®は世界約 90 力国で実施され，年間約 500 万人が受験している。日本国 内では，2009年度に 168 万人（団体特別受験制度による IP テス卜受験者 91.9 万人，公開テスト受験者 76.1 万人）が受験し， 2,700 以上の企業，団体，学校 などで昇任条件，単位認定，入学試験，クラス編成のために利用されている。 この状況は TOEIC®が世界規模で様々な用途や目的で利用されていることを 示している。しかし，その一方で，TOEIC®に対する社会的評価が確立したた めか, TOEIC®の信頼性，妥当性に関する研究は比較的限定されている。

2006 年に TOEIC@がリニューアルされたのを契機に, 我々は研究グループを 結成し，これまでに新旧 TOEIC®を古典的テスト理論とラッシュモデルを利用 して比較検証した（伊藤・島谷・法月・木下, 2009; 島谷・法月・伊藤・木下, 2009)。 そこで，本研究では TOEIC®の予測的妥当性 (predictive validity) に焦点を当て 新旧 TOEIC®の比較を試みる。

テストの予測的妥当性に関する研究はUpshur (1967) によって，その口火が 切られた。この研究はミシガン大学の人文社会科学系の大学院に通う 103 名の 学生を対象に, 英語学力と学業成績の関係を調査した。標準テストであるミシ ガンテストの得点と評定平均值の間には中程度の正の相関関係 $(r=0.4)$ が認め られた。Ayers \& Peters (1977) は工学, 化学, 数学の大学院修士課程を修了し たアジア出身の学生 50 名を対象に TOEFL®の得点と学業成績との関係を測定 したところ, Upshur (1967) と同様に中程度の正の相関係数が $(r=0.4)$ が認められ た。同様の研究である Light, Xu \& Mossop (1987) は, TOEFL®の得点と学業成 績, 専攻科目との関係を調査した結果, 人文, 芸術, 社会科学系学部に属する 学生を対象にした場合は，TOEFL®の得点と評定平均値の間には低い正の相関 が認められたが, 自然科学系学部に属する学生を対象にした場合は, 有意な相 関係数は認められなかったと報告している。Bellingham (1993) はニュージーラ ンドの工科大学の経営学部で学ぶ留学生の IELTS®の得点と, 前期の学業成績 との間に中程度の正の相関係数 $(r=0.52)$ が認められたと報告した。Lynch, Hill \& Storch (1999) は IELTS と TOEFL®の予測的妥当性を検討した。IELTS $®$ 得点 と学業成績との間には中程度の正の相関係数 $(r=0.54)$ が認められたが, TOEFL®の得点と学業成績との間には低い相関係数 $(r=0.29)$ しか求められな かったと報告した。この研究では学生に対して実施された個別インタビューの 結果に基づき，大学や大学院において優秀な成績を修めるためには，英語に関 する知識や能力とは関係のない複数の因子が複雑に関連している可能性を論じ ている。Kerstjens \& Nery (2000) は, IELTS®の得点と学業成績との間に低い正 の相関係数 $(r=0.20 \sim 0.26)$ が認められたと報告した。Denham \& Oner (1992) と Ficco (1992) は IELTS®の得点と評定平均值との間に有意な相関係数は認めら れないと報告した。Cotton \& Conrow (1998) は IELTS®の得点と学業成績との間 に負の相関係数が認められたと報告している。

これまで標準テストの予測的妥当性に関する研究を概観した。近年の言語テ スト研究における予測的妥当性に関する論考の多くは，英語の標準テストと大 学や大学院での成績の指標である学業成績との相関係数を測定し, 当該テスト 
の予測的妥当性を検証している。TOEFL®や IELTS®は留学に必要な英語学力 の指標として利用されているが，同時に英語学力を踏まえて留学中に遂行され ると想定される学術的達成度の予測もテストの目的のひとつとなっている。し かし，日本の英語教育における TOEIC®の場合は，受験者の英語以外の科目の 学業成績まで予測するために利用される可能性はほとんどない。したがって, 日本の教育現場の状況を踏まえて標準テストの予測的妥当性を検証するのであ れば，受験者の大学における英語関連科目の学業成績をどの程度予測できるの かに限定すべきである。そこで，本論文では新旧 TOEIC@の得点と大学におけ る英語関連科目の相関係数の測定, 受験者, 教員へのインタビューを実施し, 新旧 TOEIC@の予測的妥当性を検証する。

\section{方法}

\section{調查参加者}

本研究プロジェクトには，英語を外国語として学び日本の大学に在籍する 136 名（日本人学生 115 名, 留学生 21 名（中国 8 名, バングラディシュ 4 名, イン ドネシア 3 名, ネパール 3 名, ミャンマー1名, ホンジュラス 1 名, フィリピ ン1名））が参加した。受験者が在籍する大学は, 西南学院大学, 熊本大学, 静 岡産業大学, 長崎純心大学, 東京情報大学であった。受験者の所属学部は, 文 学部, 法学部, 商学部, 経済学部, 国際文化学部, 教育学部, 情報学部, 理学 部, 工学部, 薬学部, 医学部, 人文学部, 人間科学部, 総合情報学部, 大学院 教育学研究科であつた。

本調査の参加者は, 上記 136 名のうち, 同じ大学の学部学科に所属し, $6 つ$ の英語関連科目を同一時期にそろって受講した 20 名であった。1この 20 名は 大学で英語学科に属している。いずれの参加者も海外への 1 年以上にわたる長 期留学の経験はない。1 年時より所属大学のカリキュラムに沿った授業を履修 している。いずれの参加者も英語圈の文化や習慣に興味や関心を抱いている。

\section{調查材料}

予測的妥当性の対象となる TOEIC®テストの内容について記述する。TOEIC® 運営委員会が出版している TOEIC®公式問題集の中から，旧 TOEIC®問題集 (TOEIC®運営委員会, 2000) 中の「TOEIC®練習テスト」と，新 TOEIC@問題集 (TOEIC®運営委員会, 2008) 中の「TOEIC®練習テスト2」を使用して，TOEIC® Practice Test のテスト冊子を作成した。共に多肢選択方式であり, 聴解, 読解セ クション共に 100 問の計 200 問で構成されている。公式問題集の中の TOEIC® Practice Test は，実際の TOEIC@と同様の質と量であることが国際ビジネスコ ミュニケーション協会によって認定されている。したがって，本研究で得られ るデータは新旧 TOEIC®から得られるデータと同じであると考えられる。 


\section{調查手順}

\section{新IB TOEIC $\mathbb{B}^{2}$}

本論文執筆者が所属する大学の学生を中心に, TOEIC® Practice Test の参加を 募った。参加者には新旧 2 回の TOEIC®の受験が義務づけられた。テストの実 施に際し，全ての受験会場における条件が同じになるように，「テスト実施マニ ュアル」を本論文執筆者で作成し，その内容に従って実施した。受験のために テスト冊子を作成し，受験者一人ひとりに配付した。受験料は無料であった。 受験会場での口頭説明，学生への指示などは全て同一であった。受験会場にな った大学別に受験者に対して受験番号が割り振られた。テスト実施日は 2008 年 11 月から 12 月であった。いずれの実施も 1 回目のテストと 2 回目のテスト の間に 1 週間から 2 週間をあけ, 第 1 回目が旧 TOEIC®, 第 2 回目が新 TOEIC® の順序で実施した。テストの実施時間は実際の TOEIC®と同じ聴解セクション 45 分, 読解セクション 75 分の計 2 時間であり，最初の説明およびテスト制限 時間と終了後に実施された自己評価アンケートの時間を含めて約 3 時間であっ た。受験者はマークシート（教育ソフトウェア社 総合カード 103）に解答を記 入した。マークシートはテスト終了後に回収され，マークリーダー（教育ソフ トウェア社 SR-430)によってコンピュータへの入力が行われた。テスト終了後, 受験者には結果を通知し，将来的な英語学習について個別に助言を与えた。

\section{成積票}

TOEIC@受験者 136 名の中で，TOEIC®を受験した学期に同一の英語関連科目

(計 6 科目) を受講している学生が 20 名存在していることが, 受験後の調查で 明らかとなった。成績票は 2009 年 2 月に各学生に大学事務を通して各学生に配 付された。成績票のデータを収集するために 20 名の学生に対して個別に連絡を 取り，研究の目的を説明し，成績の開示を求めた。2009 年 4 月にすべてのデー 夕収集が終了した。調查対象者 20 名が所属している大学では，授業の評価を決 定する際，授業担当者である教員は 100 点満点で成績表に総合得点を記入し， その值に応じて設定された評価基準 $\mathrm{A} \sim \mathrm{E}$ を得点の横に記入する。学生には最 終評価のアルファベット表記のみが提示される。

\section{教員と学生へのインタビュー}

2009 年 4 月から 5 月に本研究の対象者である 20 名の英語関連科目の授業を担 当している教員 6 名に個別に連絡を取り，それぞれに対して 30 分程度の面談を 行った。そこで本研究の趣旨を説明し，担当した授業の内容，評価基準，英語 学力に関する考えについて意見を聞いた。各学生の最終評価（A〜E）だけでは なく, 100 点満点に換算された成績，クラスの平均点，標準偏差についても報 告してもらった。同時期に，20名の学生それぞれと面談を行い，授業内容，課 題，評価についての印象，さらには TOEIC®，英語学習についても話を聞いた。 面談時間は学生一人に対して約 40 分であった。 


\section{英語関連科目の内容}

20 名の学生が受講した 6 種類の英語関連科目について記述する。 3

\section{1. 総合英語}

英語の 4 技能を総合的に養成する授業。特に読解力と聴解力の向上を目指す。 授業では課題 (dictation) を与え， 3 週間に一度，グループ・プレゼンテーショ ンを行う。学期末には図書館で資料の収集を行い，興味のあるトピックについ て調查し，プレゼンテーション（10 分程度）を行う。最終評定は毎週行われる テスト $(30 \%)$ ，期末試験 $(50 \%)$ ，出席率（20\%）の総合評価によって決定され る。

\section{2. 英語音声基礎}

この授業では，英語の音声に関する基本的な考え方を紹介する。毎週，発音練 習を行うとともに発音方法や発音記号の読み方について学習する。最終評定は 課題 $(30 \%)$ ，期末試験 $(40 \%)$ ，出席率（30\%）の総合評価に基づいて決定され る。

\section{3. 英語演㖬 $\boldsymbol{A}$}

受講生は，異文化，外国の歴史，政治や社会のシステムに関する記事を読み，2 週間ごとに日本文化との比較を行い英語によるレポートを提出する。最終評定 は毎週行われるテスト $(40 \%)$ ，期末試験 $(30 \%)$ ，出席率 $(30 \%)$ の総合評価に 基づいて決定される。

\section{4. スピーキング $A$}

スピーキング能力の育成，特に 3 名から 4 名で行うディスカッションにおいて 話を上手に展開するためのスキルを身につける。最終評定はグループレポート $(20 \%)$ ，プレゼンテーション $(30 \%)$ ，期末試験 $(40 \%)$ ，出席率 $(10 \%)$ の総 合評価に基づいて決定される。

\section{5. ライティングA}

パラグラフを意識した文章の配列, イディオム, 英語と日本語の類似点を学ぶ。 スピーチやパワーポイントを使った効果的なプレゼンテーションの方法につい ても学習する。最終評定は課題 $(20 \%)$ ，プレゼンテーション $(30 \%)$ ，期末試 験 $(40 \%)$, 出席率 $(10 \%)$ の総合評価に基づいて決定される。

\section{6. ライティングB}

毎週 500 ワード程度のエッセイの提出が義務付けられる。英語でまとまった文 章を書く際に気をつけるべき点, 例えば接続詞の使い方, パラグラフの構成に ついて学ぶ。最終評定は課題 $(20 \%)$ ，プレゼンテーション $(30 \%)$ ，期末試験 $(40 \%)$ ，出席率 (10\%) の総合評価に基づいて決定される。 


\section{予測的妥当性の检証方法と分析基準}

本調査では科目別に与えられた成績の 100 点満点の值と TOEIC®の得点との間 のピアソンの積率相関係数を測定することで，TOEIC®の得点が受験者の成績 をどの程度予測しているか検討する。 ${ }^{4} \mathrm{TOEIC} @ の$ 得点については，聴解，読解 の各セクションの素点 (100 点満点) を求め, 次に上記の各公式問題集の換算 值レンジ表に基づいて換算上限值と下限値を確認した上で，上限值と下限值の 中央值を計算し，この各セクションの換算中央值の合計を便宜的に TOEIC®の 得点として扱うこととした。さらに，6つの英語授業の総合的な評価を求める ため, 各授業を担当した教員に最終評価の平均値と標準偏差の測定を依頼した。 そのデータをもとに 20 名の各授業における最終評価の值を偏差値に変換した。 次に偏差值の和を科目数，すなわち 6 で割り，6つの英語関連科目の総合評定 平均值を求めた。 5

言語テスト研究において, 予測的妥当性の判断基準そして，ピアソンの積率 相関倸数が利用されることが多い。実施されたテストに予測的妥当性が備わっ ていると判断するには, 当該テストの得点と評定平均值の間に 0.3 から 0.4 程度 の相関係数が必要であると考えられている (Kaplan \& Sacuzzo, 1997)。最近の研 究では調査参加者が等質な集団で構成されている場合は, 0.4 以上の相関係数が 認められるべきと考えられている(Talento-Miller \& Rudner, 2005a, 2005b)。

本調査では, 同じ大学に通い同じ授業を受講する日本人英語学習者が対象と なっているため，等質性が高い集団と考えられる。したがって，0.4 以上の相関 係数が認められる場合について予測的妥当性が備わっていると判断する予定で あった。しかし, 今回の調査における参加者は 20 名であり, 自由度の值が小さ いため, 相関係数が 0.444 以上の值を示さなくては, $5 \%$ 水準で統計的に有意で あると判断できない。本調査では相関係数が 0.45 以上の值を示さない場合は TOEIC®に予測的妥当性が備わっているとは判断できないことにした。 ${ }^{6}$

結果

表 1 は新旧 TOEIC@における調査参加者の平均点と標準偏差を示している。調 查参加者 20 名の新旧 TOEIC®の平均点の間には統計的有意差は存在しなかっ た $(t=0.021, p=0.889$, n.s. $)$ 。 
表 1 : 基本統計值 $(N=\mathbf{2 0})$

旧 TOEIC® 新 TOEIC®

$\begin{array}{ccc}\text { 調查参加者数 }(N) & 20 & 20 \\ \text { 満点 }(\text { Full Score) } & 990 & 990 \\ \text { 平均点 }(M) & 626.818 & 627.727 \\ \text { 標準偏差 }(S D) & 82.387 & 118.980\end{array}$

表 2 : TOEIC®と評定值とのピアソンの積率相関係数一覧

\begin{tabular}{ccccccc}
\hline 授業 & 旧・聴解 & 旧・読解 & 新・聴解 & 新・読解 & 旧・全体 & 新・全体 \\
\hline 総合英語 & $0.626^{*}$ & 0.109 & 0.337 & 0.426 & 0.395 & 0.418 \\
英語音声基礎 & 0.294 & 0.168 & 0.356 & $0.703^{*}$ & 0.261 & $0.609^{*}$ \\
英語演習 A & $0.612^{*}$ & $0.522^{*}$ & 0.134 & 0.331 & $0.653^{*}$ & 0.273 \\
スピーキング A & $0.700^{*}$ & 0.343 & 0.199 & $0.473^{*}$ & $0.584^{*}$ & 0.393 \\
ライティング A & $0.810^{*}$ & 0.242 & -0.062 & 0.067 & $0.576^{*}$ & 0.019 \\
ライティング B & 0.296 & 0.139 & $0.576^{*}$ & $0.778^{*}$ & 0.243 & $0.747^{*}$ \\
\hline
\end{tabular}

表 2 は新旧 TOEIC®の得点と $6 つ$ 英語関連科目の評定值とのピアソンの積率 相関係数を示している。新旧 TOEIC®は, 聴解セクション, 読解セクション, 全体の 3 つに分類されて表示されている。

旧 TOEIC®の聴解セクションは, 4 つの授業 (「総合英語」, 「英語演習 $\mathrm{A}\rfloor$, 「ス

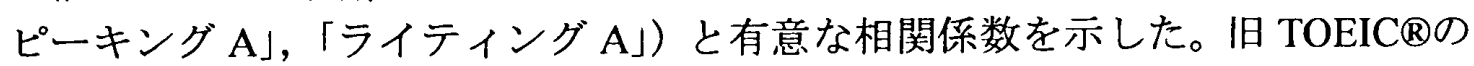
読解セクションは「英語演習 $\mathrm{A} 」$ と有意な相関係数を示した。

新 TOEIC@の聴解セクションは,「ライティング B」と有意な相関係数を示し

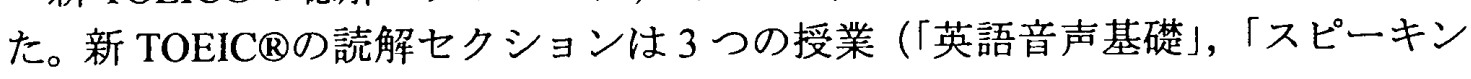

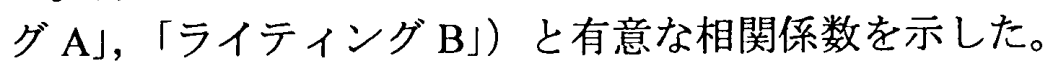

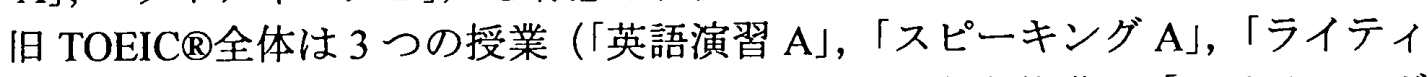
ング $\mathrm{A}\rfloor$ ）と，新 TOEIC®全体は 2 つの授業（「英語音声基礎」，「ライティング B」）と有意な相関係数を示した。

調査対象者の 6 つの英語関連科目それぞれにおける評定の偏差値を求め, 偏 差值の平均值を総合評価の指標とした。この指標と TOEIC®の得点間のピアソ 
ンの積率相関係数を測定したところ，旧 TOEIC®は $r=0.456, p<.05$, 新 TOEIC® は $r=0.324$, n.s. であった。

これまでの相関係数による報告では，2つの母相関係数を個別に検定してい るので，新旧 TOEIC®の測定している英語学力の内容が同じかどうかを検証し ているわけではない。同様に旧 TOEIC®と6つの授業の評定平均値との相関係 数は有意となり，新 TOEIC®との相関係数は有意ではなかったが，2つの相関 係数の差に関する検定は行われていない。そこで，2 つの相関係数の差が統計 的に有意であるかどうかを，Hotelling-Williams test (Brannick, 2010) を利用して 検定した。

英語関連科目と新旧 TOEIC@の聴解セクション，読解セクション，全体との 間の相関係数の差が統計的に有意かどうかを検定した結果, 聴解セクションと

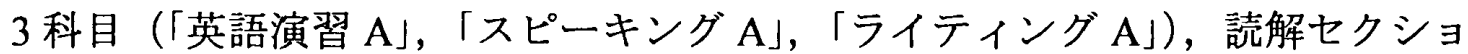
ンと 2 科目 (「英語音声基礎」,「ライティング B」)の相関において, 新旧 TOEIC® の間で有意差が確認された。以下に詳細を述べる。

「英語演習 $\mathrm{A}\rfloor$,「スピーキング $\mathrm{A}$,「ライティング $\mathrm{A} 」 の 3$ 科目は, 新 TOEIC® の聴解セクションよりも旧 TOEIC®の聴解セクションに, より高い相関係数を 示していることが確認された (「英語演習 $\mathrm{A} 」(t=2.881, p<.01)$; 「スピーキング $\mathrm{A} 」$ $(t=3.346, p<.01) ;\lceil ラ イ テ ィ ン ク ゙ ~ A 」 ~(t=13.000, p<.01)) 。$

「英語音声基礎」,「ライティング B」の 2 科目は, 旧 TOEIC@の読解セクシ ヨンよりも新 TOEIC®の読解セクションに, より高い相関係数を示しているこ とが確認された(「英語音声基礎」 $(t=-5.341, p<.01)$,「ライティング $\mathrm{B}\rfloor(t=-14.151$, $p<.01)$ 。

6 つの英語関連科目と新旧 TOEIC®との相関倸数には有意差は存在しなかっ た $(t=0.840$, n.s. $)$ 。

\section{考察}

上記の結果に考察を加える。表 2 の相関行列を見る限り，新旧 TOEIC@それぞ れが統計的に有意な相関係数を示した科目名が異なるように見えた。 ${ }^{7}$ しかし， 相関係数の有意差検定により，以下の点が示唆された。

旧 TOEIC@の聴解セクションは $3 つ$ 英語関連科目（「英語演習 $\mathrm{A}\rfloor$, 「スピー

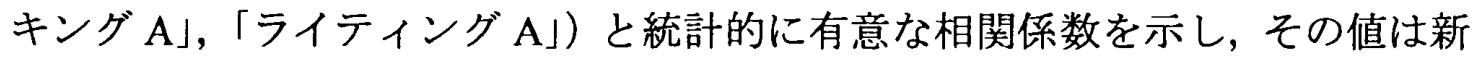
TOEIC®の聴解セクションよりも高かった。さらに，新 TOEIC®の読解セクシ ヨンは 2 つ英語関連科目（「英語音声基礎」,「ライティング $\mathrm{B} 」$ ） と統計的に 有意な相関係数を示し，その值も旧 TOEIC®の読解セクションよりも高かった。

以上から，6つの英語関連科目のうちの 5 つは新旧 TOEIC®どちらか一方の 聴解，読解のいずれかのセクションと統計的かつ有意に高い相関倸数を示した と解釈できる。この結果から，新旧 TOEIC®いずれも全体としては大学におけ 
る英語関連科目の評定值を予测するに十分な妥当性を有しているとはいえなか ったが，各セクションは複数の英語関連科目に対してある程度の予測的妥当性 を有していることが示唆されたといえる。

なぜ上記のような結果が得られたか検討してみたい。旧 TOEIC®の聴解セク

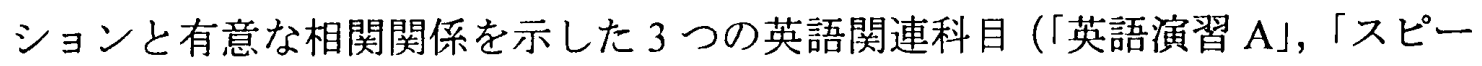

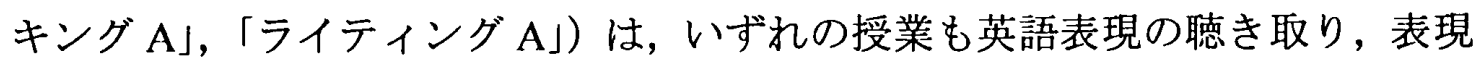
の暗記, 小テスト (quiz) の3つの活動が毎回の授業で実施されていた。3名の 教員のうち, 特に 2 名は「音声面への理解が十分でなければ英語を意思伝達の 方法として利用することにはならない」との教授哲学をもつ英語母語話者（イ ギリス人，アメリカ人）であった。調査参加者である学生によれば「授業の題 目が異なるが実際の内容はかなり似ていると言えなくもない」よだ。さらに, 学生たちにこれらの教員 2 名の授業について印象を聞いたところ, 17 名の学生 が「授業内容にとても満足」しており，「2名の教員は授業に熱心」であると答 えた。13 名の学生は,これらの教員による別の授業を受講した経験を有してい た。別の授業でも基本的な授業展開や課題の形式（英語の聴き取り課題）は共 通していたと答えた。以上の点から聴解セクションと 3 つ英語関連科目が統 計的に有意な相関を示したことは不思議ではないと結論できる。では，なぜ旧 TOEIC®の聴解と間に，より高い相関係数を示したのであろうか。現時点では この点に関する明確な根拠を見つけ出すことはできないので，今後の課題とし たい。

次に新 TOEIC®の読解セクションと有意な相関関係を示した「英語音声基礎」 と「ライティング B」について検討を加える。「英語音声基礎」を担当した教員 は学生の授業内パフォーマンス, 特に発音練習に対して厳格な指導を行い, 発 音のチェックテストを毎回の授業で実施し，その結果を最終評価に反映させて いた。学期終了後，20名の学生全員が単位を認定されたが，彼らの成績は非常 に多様であり，成績の標準偏差の值は 6 つ英語関連科目の中で最も大きかつ た。調査参加者 20 名の新旧 TOEIC®の結果では, 新 TOEIC®読解の標準偏差の 值が最も高かったことから，学生のレベルをより広い範囲に弁別できたセクシ ヨンと高い相関を示したと考えられる。

「ライティング B」の授業はエッセイの提出が義務付けられるとともに，書 く活動の前提条件として読む活動が強調されている点は受講者の半数以上の学 生（12 名）から指摘があった。したがってライティング能力の育成が最終目標 の授業ではあるが，同時に授業の方針や実際の内容が読解力の養成に寄与して いた可能性がある。「ライティング B」は「英語音声基礎」の次に学生の評定值 の標準偏差が高かったことも，このような結果を導いたかもしれない。

新旧 TOEIC@全体と 6 つの英語関連科目との相関係数の間には有意差は存在 しなかった。したがって，新旧 TOEIC®全体では，6つの関連科目に対して同 じ程度の相関関係を有するとしか現時点では結論付けられない。旧 TOEIC®は 本研究において設定した予测的妥当性検証の基準である 0.45 を若干上回ったが $r=0.456, p<.05$, 新 TOEIC®は $r=0.324, n . s$. は基準を下回った。新旧 TOEIC®そ 
れぞれで異なる結果が出たため，2 つの相関係数に統計的に有意な差がないと いう結果は解釈を難しくさせる。新旧 TOEIC®全体は，ともに予測的妥当性が 低い，または新旧 TOEIC®全体はともに十分な予測的妥当性を有する，との 2 つの解釈が可能となる。聴解セクションと読解セクションを一体として構築さ れている TOEIC®がテスト全体として, どの程度の予測的妥当性を示すのか, 今後も検討していかなければならない。

6 つの英語関連科目のうち「総合英語」は TOEIC®と何ら有意な相関係数を 示すことがなかった。しかし，TOEIC®と相関関倸を示さなかったからといっ て，この授業の内容や質に問題があると断定することはできない。「総合英語」 の授業で教員が何を教授し，どのような活動が行われているかを詳細に描写し 検討すれば，TOEIC®では測定できない学生の英語能力の側面や，言語テスト による測定と評価の限界を知ることができるかもしれない。

本研究の目的のために遂行したインタビューにおいて，「総合英語」の担当教 員が発言した内容を以下に紹介する。

複数の日本の大学で英語を教えていて感じることだが，TOEIC@で高得点を取 る学生を育成することに終始するあまり，英語を使う，英語を通してより多く の知識を身につけたり，考えたり才ることがおざなりになっていないか。英語 の学力はもっと多样な能力 (multiple-competence) であるはずだ。

この発言をした段階では,「総合英語」を担当する教員は本研究の結果を知らさ れていなかった。この教員は常に，資格検定試験や標準テストで測定され評価 される英語学力よりも, 人と人が実際に意思の伝達を試みる際に必要とされる 英語学力は何かを哲学的に考えている教員であり, 授業でも標準テストや資格 検定試験の先にある目標を学生に意識させようとしている。

TOEIC@が単位認定やプレイスメントテストとして日本の英語教育に導入さ れ, 教員, 学生にとって有益なことも少なくないはずだ。しかし同時に, 学生 に TOEIC®で高得点を取らせるための指導が唯一の目標となる可能性には注意 が必要である。 8 英語教育活動を通して, 目の前の学習者が将来どのように成 長してほしいのか, その理想像を明確にしなければ，テストのための英語学習 に終始してしまう。標準テストの利便性を最大限に生かすため, TOEIC@を英 語教育活動の中でどのように利用していくのか,「総合英語」担当者の教員の言 葉を踏まえて, 我々は今一度, 標準テストの利用の仕方を検討する必要がある だろう。

最後に本研究結果の解釈に関する注意事項を明記しておきたい。本調查参加 者の TOEIC®の得点は, TOEIC®のスコアシートで提示される約 990 点満点の 指標において， 600 点前後に位置することから分かるように，日本人英語学習 者の中では比較的，英語能力の高い集団である。TOEIC®のスコアが 300 点か 
ら 400 点程度の学習者の場合, 聴解セクションと読解セクションのスコア間の ピアソンの積率相関係数の值が負の相関を示すことがある。この負の相関現象 は受験者の得点レンジが 500 以上になると次第に低い正の相関に変化し, 高得 点に移行するにつれて相関は高くなっていく。得点の低い受験生の場合, テス トに表れる数值としての聴解力と読解力が不安定な状態であり, 言語テスト研 究で言われるような「聴解力と読解力には高い正の相関」(Buck, 1992) を裏づ ける状態ではない。したがって, 今回の受験者集団の学力レベルが研究結果に 影響を与えている可能性は否定できない。

\section{結論}

本研究では TOEIC®の予測的妥当性を検証した。調査参加者は日本の大学で英 語を学ぶ学生 20 名であった。新旧 TOEIC®の得点と $6 つ$ つ英語関連科目の評定 值との相関係数を測定し，その結果を基に新旧 TOEIC®の予測的妥当性の検証 を行った。その結果, 新旧 TOEIC@は大学における英語関連科目の評定值を予 測する妥当性を有しているかどうか明確な結論を導くことはできなかった。し かし, 各セクションは複数の英語関連科目に対してある程度の予測的妥当性を 有していることが示唆された。新旧 TOEIC®の各セクションと有意な相関係数 を示した英語関連科目については, 学生と担当教員とのインタビューの内容を 基に，その理由について検討を試みた。

\section{今後の課題}

今後の研究課題としては, 大学でプレイスメントテストとして TOEIC®を受験 している学生が TOEIC®をどのようなテストだと認識しているかを検討寸る必 要がある。標準テストが導入されると, 社会に様々な影響を及ぼす可能性が指 摘される。しかし, 学習者を例にとった場合, ある特定の学習者が標準テスト にどのような影響を受けるのか事例的に検討されることはほとんどない。標準 テストで英語学力が高いと評価されるようになればなるほど, テストのための

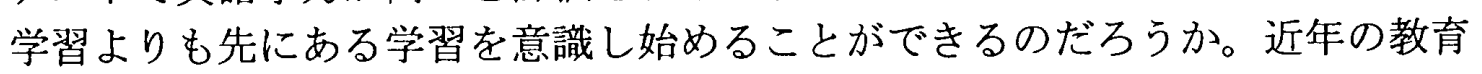
学研究の影響により教育評価の一端を担っている言語テスト研究においても, 個人に焦点を当てた研究が行われるべきである。近年のテストの妥当性研究が 定量分析で占められていることの反省も踏まえ, テス卜受験者個人が標準テス 卜によって英語能力を測定されることをどのように認識しているのか,「個人の 態度構造」(内藤, 1993, 2002) を検討する必要がある。 


\section{謝辞}

本研究のデータ収集に際し, 西南学院大学, 熊本大学, 静岡産業大学, 長崎純 心大学, 東京情報大学の学生および関係者の方々, そして鈴木千鶴子先生（長 崎純心大学）に多大なご協力を賜った。財団法人国際ビジネスコミュニケーシ ヨン協会研究開発部長の三橋峰夫氏には研究計画の立案と調査実施に際し, 様々な助言を賜つた。これらの方々にこの場を借りて感謝の意を表明したい。 本研究は財団法人国際ビジネスコミュニケーション協会の TOEIC®研究助成金 (研究題目「新旧 TOEIC®の比較とプレイスメントテストとしての妥当性」(研 究代表者：伊藤彰浩 西南学院大学教授）（研究実施期間 : 2008 年 4 月～2010 年 3 月）により実施された。

\section{註}

1. 調査対象の 20 名のうち, 12 名が大学 2 年生, 8 名が大学 3 年生であった。大 学 2 年生の 12 名の中で 1 年以上の長期海外居住経験を有しているものはいな かった。大学入学後は 12 名中 11 名が同一の英語関連科目を履修している。1 名は 1 つの英語関連科目の授業について 1 年時の後期（秋学期）に別の授業 を履修していた。3 年生 8 名のうち，6 名は 1 年生, 2 年生, 3 年生の前期ま で英語授業については全て同じ授業を履修しており，英語関連科目について は，この時点で同じ授業を履修しているといえる。このような比較的等質な 集団を抽出できた理由は，アドバイザーの教員を通して TOEIC® Practice Test の開催を伝えたため, 同一の授業を多数履修し親しい間柄であるクラスメ一 トと一緒に申し込みをしたからであると推測される。

2. 新旧 TOIC®を比較すると測定される構成概念については，これまで筆者らが 執筆した論文（伊藤・島谷・法月・木下, 2009; 島谷・法月・伊藤・木下, 2009） を参考にされたい。2006 年のリニューアルを機に, TOEIC®の測定する英語能 力にどのような変化があるか検証することが, 我々の研究プロジェクトの目 的のひとつである。しかし, 本論文で報告する研究の目的は TOEIC®公式問題 集で公開されている新旧の TOEIC®を新旧バージョンの代表として提示し， 2 つの TOEIC®が英語関連科目における学習者個人の成績をどの程度予測でき るか調査することに限定されている。

3. 英語母語話者の教員が担当する授業は，指示や解説も全て英語で行われてい る。したがって，教員の意図を理解し，積極的に授業に参加し課題を遂行す るには英語の聴解力が必要不可欠である。さらに匿名査読者より6つの授業 で実際に養成されている能力・スキルの詳細を明らかにするように提案を受 けた。筆者としては，より厳密な研究を行う上でその様な視点は重要である と考えている。しかし，6つそれぞれの授業で養成されている英語学力を比較 し，その相違点を論じることは不可能であり，シラバス，教員へのインタビ 
ユ一，受講した学生へのインタビュ一から想像するしか方法はない。今後は 客観的に授業のねらいや授業で利用されている英語のレベルを記述する方法 を検討したいと考えている。

4.「参加者 20 名は TOEIC®を 2008 年 11 月と 12 月に受験し，同時期に同一の英 語関連科目を履修しているので TOEIC@の成績と英語関連科目との相関では 予測的妥当性を検討できない」との解釈も十分に可能である。一方，筆者ら が基づく考えは，基準関連妥当性を併存的妥当性と予測的妥当性とに分類し， あるテストやアンケートの妥当性を测定する際に，その外的基準を提供する データが，ほぼ同時期に得られる場合には併存的妥当性の検証になり，基準 值がその後に得られる場合は，予測的妥当性の検証になる，というものであ る。しかしながら, 今後, 前者の解釈にも対応できるように, 実施時期の明 らかに異なるテストやその他の評価手法間での関係の分析を行い，予測的妥 当性の検証を行う必要性もあると認識している。

5. 本調査の参加者は同一の授業を受講している学習者集団であるため, TOEIC® の得点と評定值の相関を取る際には問題はない。しかし，考察で述べた評価 得点の平均を論じる際には，教員が異なれば評価基準は異なり，タイプの異 なる複数の授業を標準化してその平均を測定する必要がある。そこで，担当 教員に評定の平均值と標準偏差を教えてもらい, 各被調査者の授業ごとの評 定值の偏差值を测定し，それらの和を求めて平均を測定した。最終的には, その值をすべての授業の評価值の平均値として算出した。

6. 予測的妥当性に関する先行研究では，相関係数 0.4 を妥当性の判定基準に設 定する場合が多いため，今回の研究ではその慣例に従った。調査対象者が 20 名と少ないため， 0.45 が結果的に相関係数の有意性検定の基準になってしま ったが，これは意図的に行ったものではない。さらに，データ提供者個人の 情報を保護する観点から, 本研究で使用したデータに関する質問には一切答 えられない。データ提供者との間には, 本研究の意義を説明し, 成績内容の 提供による不利益を被らない等の説明に加え，情報提供の場合には，そのデ 一タが正しいものかを確認するために提供者が持参した成績票を見たが，そ のデータを記入した用紙については入力終了後に提供者にその場で返却し破 棄するようにお願いした。統計分析を行う際には学生のデータは番号によっ て認識できるようにし，個人を特定できる情報は使用しなかった。本研究で 利用した研究デザインは, 近年の社会科学研究法の一つとして注目を浴びて いるミックス法 (混合法) (Tashakkori \& Dalie, 2003) で考えられているものに 近いが，一部及ばない点もある。ミックス法の本来の目的は，テストの妥当 性研究を行う際, 関連する量的, 質的データを複数収集し, それらを研究者 自身がまとめあげる努力をする過程を通して, 複雑な現象を総合的に理解し ようとする営みである。今後はより厳密に TOEIC®にかかわる複数の諸相を明 示し, 受験者の TOEIC@得点を踏まえて行われる解釈や意思決定に対して, 教 員, 学生, 学校がどのようにかかわっているか検討する必要がある。 
7. 同一学部同一学科の学生のみでデータ収集をしたことが，相関係数の高さに 寄与しているかもしれない。匿名査読者から指摘があったように，相関係数 の值がテストと TOEIC®のセクションによってばらついているのは,様々な要 素が絡まり合った結果である可能性がある。しかし，この種の研究で重要に なるのは様々な要素や要因が複雑に絡み合った状況でも社会的に認知されて いる標準テストが受験者の授業内でのパフォーマンスとの関倸性を示唆する のか調查することである。具体的な要素や要因の解明は今後の研究において 受験者個人を対象としたミックス法による調査を実施する必要がある。

8. その一方で学生の目標意識において, TOEIC $囚 の$ 得点を上昇させることが第 1 目標となっている可能性もあるため, 教員が授業を展開する中で，学生の期 待に応えるため, 意識的にせよ無意識的にせよ, TOEIC®の得点を上昇させる と考えられる内容を扱うこともありうる。標準テストの導入によって, 大学 英語教育におけるカリキュラムだけではなく，そのカリキュラムに基づいて 授業を展開する教員と，そこで学ぶ学生たちの態度や意識に対する研究は, 要因の多さと複雑さが相まっているため研究の遂行が難しいかもしれないが, 今後はこれらの点にも着目して研究を行う必要がある。

\section{参考文献}

Ayers, J. B., \& Peters, R. M. (1977). Predictive validity of the test of English as a foreign language for Asian graduate students in engineering, chemistry, or mathematics. Educational and Psychological Measurement, 37, 461-463.

Brannick, M.T. (2010). Multiple regression; research methods by Michael Brannick: Available online at http://luna.cas.usf.edu/ mbrannic/index.html\#TOP

Buck, G. (1992). Translation as a language testing procedure: Does it work? Language Testing, 9 (2), 123-148.

Bellingham, L. (1993). The relationship of language proficiency to academic success of international students. New Zealand Journal of Educational Studies 30, 229-232.

Cotton, F., \& Conrow, F. (1998). An investigation of the predictive validity of IELTS® amongst a group of international students studying at the University of Tasmania. IELTS $®$ Research Reports 1998 Vol. 1.

Denham, P. A., \& Oner, J. A. (1992). IELTS research project: Validation study of listening sub-test. IDP/IELTSß commissioned report/University of Canberra.

Fiocco, M. (1992). English proficiency levels of students from a non-English speaking background: A study of IELTS® as an indicator of tertiary success. Unpublished research report. Perth: Curtin University of Technology.

Kaplan, R. \& Sacuzzo, D. (1997). Psychological testing: Principles, applications, and 
issues (Fourth Edition). Pacific Grove, CA: Brooks/Cole Publishing Company. Kerstjens, M., \& Nery, C. (2000). Predicative validity in the IELTS® test: A study of the relationship between IELTS® scores and students' subsequent academic performance. IELTS $®$ Research Reports 2002 Vol. 3.

Lee, H.-K. (2004). Constructing a field-specific integrated writing test for an ESL placement procedure. Unpublished doctoral dissertation, University of Illinois at Urbana-Champaign.

Light, R. L., Xu, M., \& Mossop, J. (1987). English proficiency and academic performance of international students. TESOL Quarterly, 21, 251-261.

Lynch, B., Hill, K., \& Storch, N. (1999). A comparison of IELTS® and TOEFL® as predictors of academic success. IELTS Research Reports 1999 Vol. 2.

Talento-Miller, E. \& Rudner, L. M. (2005a). Which programs have the highest validity: Identifying characteristics that affect prediction of success. GMAC ${ }^{\circledR}$ Research Reports (RR-05-03), 1-7.

Talento-Miller, E. \& Rudner, L.M. (2005b). VSS summary report for 1997-2004 (RR-05-06). McLean, VA:Graduate Management Admission Council®.

Tashakkori, A., and Teddlie, C. (2003). Handbook of mixed methods in social and behavioral research. Thousands Oaks, CA: Sage.

Upshur, J. A. (1967). English language tests and prediction of academic success. National Association of Teachers of English as a Second Language: Studies and Papers (English Language Series), 13, 85-92.

伊藤彰浩・島谷浩・法月健・木下正義. (2009). 「古典的テスト理論による新・

旧 TOEIC®の比較分析」『日本言語テスト学会紀要』12, 26-45.

国際ビジネスコミュニケーション協会. (2009)『TOEIC®テスト DATA\& ANALYSIS 2009』東京：財団法人国際ビジネスコミュニケーション協 会.

島谷浩・法月健・伊藤彰浩・木下正義. (2009).「ラッシュモデルによる新・ 旧 TOEIC®の比較分析」『大学英語教育学会九州・沖縄支部研究紀要』 14, 17-32.

TOEIC@運営委員会. (2000).『TOEIC®テスト公式問題集』東京：財団法人国際 ビジネスコミュニケーション協会 TOEIC®運営委員会.

TOEIC@運営委員会. (2008).『TOEIC®テスト新公式問題集』東京：財団法人国 際ビジネスコミュニケーション協会 TOEIC®運営委員会.

内藤哲雄. (1993).「個人別態度構造の分析について」『人文科学論集』27, 43-69. 内藤哲雄. (2002). 『PAC 分析実施法入門』京都 : ナカニシヤ出版. 